\title{
Stylicins, a new family of antimicrobial peptides from the Pacific blue shrimp Litopenaeus stylirostris
}

\author{
J.L. Rolland ${ }^{a}{ }^{*}$, M. Abdelouahab ${ }^{b}$, J. Dupont ${ }^{c}$, F. Lefevre ${ }^{c}$, E. Bachère ${ }^{a}$ and B. Romestand ${ }^{a}$ \\ ${ }^{a}$ IFREMER, Université Montpellier 2, Centre National de la Recherche Scientifique, IRD, UMR 5119 \\ «Ecosystèmes Lagunaires», Place E. Bataillon, CC80, 34095 Montpellier cedex 5, France \\ ${ }^{\mathrm{b}}$ Université Catholique de Louvain, Unité de Microbiologie (MBLA), Croix du Sud 03, boîte 06, B1348 Louvain-la- \\ Neuve, Belgium \\ ${ }^{\mathrm{c}}$ LibraGen, 3 rue des Satellites, Bâtiment Canal Biotech I, 31400 Toulouse, France \\ *: Corresponding author : J.L. Rolland, Tel.: +33 4671447 09; fax: +33 4671446 22, email address : \\ Jean.Luc.Rolland@ifremer.fr
}

\begin{abstract}
:
The present study reports the characterization of Ls-Stylicin1, a novel antimicrobial peptide from the penaeid shrimp, Litopenaeus stylirostris. The predicted mature peptide of 82 residues is negatively charged (theoretical $\mathrm{pl}=5.0$ ) and characterized by a proline-rich $\mathrm{N}$-terminal region and a C-terminal region containing 13 cysteine residues. The recombinant Ls-Stylicin1 has been isolated in both monomeric and dimeric forms. Both display strong antifungal activity against Fusarium oxysporum $(1.25 \mu \mathrm{M}<\mathrm{MIC}<2.5 \mu \mathrm{M})$, a pathogenic fungus of shrimp, but lower antimicrobial activity against Gram (-) bacteria, Vibrio sp. $(40 \mu \mathrm{M}<\mathrm{MIC}<80 \mu \mathrm{M})$. However, rLs-Stylicin1 is able to agglutinate Vibrio penaeicidae in vitro in agreement with its potent LPS-binding activity on immobilized LPS of $V$. penaeicidae (dissociation constant $\left(K_{\mathrm{d}}\right)$ of $9.6 \times 10^{-8} \mathrm{M}$ ). This molecule with no evident homology to other hitherto described antimicrobial peptides but identified herein several species of penaeid shrimp is thought to be the first member of a shrimp antimicrobial peptide family, which we termed stylicins.
\end{abstract}

Keywords: Ls-Stylicin1; Peptide; Shrimp; Antifungal; Agglutination; Vibrio 


\section{Introduction}

Infectious diseases are one of the main limitations to the sustainable development of shrimp aquaculture worldwide. Over the past 20 years, progresses have been made in the understanding of shrimp immunity, through the characterization in particular of antimicrobials and other defense molecules (Aguirre-Guzman et al., 2009).

Several families of antimicrobial peptides have been isolated. Those include penaeidins, isolated the first time from the Pacific white shrimp Litopenaeus vannamei (Destoumieux et al., 1997) and which primary structure are characterized by the presence of a $\mathrm{N}$-terminal domain rich in proline residues and a C-terminal domain containing 6 cysteine residues (Destoumieux et al., 2000). Penaeidins display antifungal and antibacterial activity with a predominant activity against Gram-positive bacteria (Bachère et al., 2000) and agglutinating activity against Vibrio strains (Munoz, 2002). Cysteine-rich antimicrobial peptides from shrimp also include crustins, possessing 12 cysteine residues and a wheyacidic-protein domain (WAP) and exclusively active against Gram-positive bacteria (Bartlett et al, 2002; Zhang et al; 2007; Amparyup et al., 2008). Also antilipopolysaccharide factor (ALF) such as recombinant form of ALFpm3 (Amparyup et al., 2008) exhibited a broad spectrum of activity against various strains of bacteria and fungi and was able to reduce WSSV propagation and prolong the survival of shrimps. Also lysozyme such as lysozyme C (Mai et al., 2009) from the blue shrimp (Litopenaeus stylirostris) demonstrated to be not only active against Gram-positive and Gram-negative bacteria but also against shrimp pathogens Vibrio sp.

Besides antimicrobial peptides, several effectors of shrimp immunity have been characterized that are involved in the recognition of microorganisms by binding molecules on the surface of invading bacteria. To date, those Pattern Recognition Proteins (PRPs) 
monodon, a lipopolysaccharide binding protein which has strong hemagglutinating and bacterial-agglutinating activity as well as opsonic effect (Luo et al., 2006).

In spite of such progresses, the mechanisms by which the shrimp can circumvent infections remain largely unknown. Thus, the capacity of the shrimp Litopenaeus stylirostris to survive an infection with the highly pathogenic bacteria Vibrio penaeicidae have been investigated (de Lorgeril et al., 2005) by genomic approach. Thus, a relationship has been evidenced between the successful anti-infectious response of the shrimp and the abundance of transcripts for genes involved in immunity. Among them, genes encoding antimicrobials have been evidenced such as penaeidin 3 and lysozyme. Interestingly, a new transcript encoding a putative peptide rich in cysteines (13 Cys) and prolines was also identified. This transcript presented sequence homologies with a mouse cryptdin-related mRNA (Ouellette et al., 1990). Abundantly expressed in the haemocytes of shrimp able to survive the infection, the peptide could be involved in the immune response against the pathogenic bacteria.

In this report, we have further characterized this new cysteine and proline-rich peptide and investigated its biological properties in terms of antimicrobial, LPS-binding and agglutinating properties. For that, a recombinant peptide was produced in Escherichia coli system and purified to homogeneity. The "cryptin-like” peptide from the initial study (de Lorgeril et al., 2005) was renamed here Ls-Stylicin1 after the name of the shrimp Litopenaeus stylirostris.

\section{Materials and methods}

\subsection{Nucleic sequences analysis}

Total genomic DNA was extracted from the haemocytes of juvenile L. stylirostris according to the Current Protocols in Molecular Biology (Wiley et al., 2003) as well as total mRNA using Trizol (Invitrogen) for cDNA synthesis (Invitrogen). Based on Litsty 004-A-01 
L, the cDNA sequence identified by de Lorgeril, GenBank/EMBL Data Bank with the accession number $\underline{\mathbf{C V 6 9 9 2 7 4}}$ (de Lorgeril et al., 2005), homologous primers, R1F (5'ATGAAGACCTACAGTC-3’) and R1R (5'-GACTGTAGGTCTTCAT-3’) were designed and used for PCR amplification. The reaction was performed by incubating the reaction mixtures at $94{ }^{\circ} \mathrm{C}$ for $10 \mathrm{~min}$, followed by successive cycles at $94{ }^{\circ} \mathrm{C}$ for $1 \mathrm{~min}, 55^{\circ} \mathrm{C}$ for 1 min, and $72{ }^{\circ} \mathrm{C}$ for 1 min for 30 cycles using Taq DNA polymerase (Qbiogene). Amplification products were then cloned into TopoTA cloning vector (Invitrogen) for sequencing. The subsequent sequences (DNA and cDNA) were compared with those available in Genbank data bases at the National Center for Biotechnology Information (NCBI) using the BLAST network service. Sequence alignments were made using Clustal W (Higgins et al., 1992) and Multalin programs (http://bioinfo.genopoletoulouse.prd.fr/multalin/multalin.html). Peptide sequences were analysed by the Blast and ScanProsite Tools.

\subsection{Recombinant expression}

Recombinant L. stylirostris Stylicin1 (rLs-Stylicin1) was expressed in E. coli as an Nterminal His6-tagged fusion protein using the pET-28b (+) system (Novagen, Madison, WI). A Met-coding trideoxynucleotide was incorporated 5' of the Ls-Stylicin1 cDNA and cloned in-frame with the N-terminal His6 in the BamH1/Sac1 sites of pET-28a (+) by PCR amplification,

using forward

primer

R2F (5'GTCTTGCACACGGGATCCATGTCTTCCTTTTCACC-3') paired with reverse primer R2R (5'-GTGGCTTCGTTCTCGAGCTCTTATCCTTTATAACC-3'). The reaction was performed by incubating the reaction mixtures at $94{ }^{\circ} \mathrm{C}$ for $10 \mathrm{~min}$, followed by successive cycles at $94{ }^{\circ} \mathrm{C}$ for $1 \mathrm{~min}, 55^{\circ} \mathrm{C}$ for $1 \mathrm{~min}$, and $72{ }^{\circ} \mathrm{C}$ for $1 \mathrm{~min}$ for 30 cycles using Taq DNA polymerase (Qbiogene). The underlined codon in the forward primer denotes a Met codon to 
incorporate a $\mathrm{CNBr}$ cleavage site immediately upstream of the $\mathrm{N}$-terminus of the designed peptide. The construction was sequenced using an ABI Prism 377 DNA sequencer. The rLsStylicin1 was expressed in E. coli BL21 (DE3) pLysS cells (Novagen) transformed with the pET-28a (+)/rLs-Stylicin1 construct. The cells were grown at $37{ }^{\circ} \mathrm{C}$ to $A_{600} 0.8$ in LuriaBertani (LB) medium (10 g of bacto-Tryptone, $5 \mathrm{~g}$ of bacto yeast extract, and $10 \mathrm{~g}$ of $\mathrm{NaCl}$ ) supplemented with $50 \mu \mathrm{g} / \mathrm{ml}$ kanamycin. Expression of fusion proteins was induced with 0.5 $\mathrm{mM}$ isopropyl- $\alpha$-D-1-thiogalactopyranoside. After growth at $37{ }^{\circ} \mathrm{C}$ for $12 \mathrm{~h}$, bacterial cells were harvested by centrifugation and stored at $-20^{\circ} \mathrm{C}$. The cells were lysed by resuspension in $6 \mathrm{M}$ guanidine $\mathrm{HCl}$ in $100 \mathrm{mM}$ Tris- $\mathrm{HCl}, \mathrm{pH}$ 8.1, followed by sonication at $40 \%$ amplitude for 2 min using a Vibra cell Sonifier 450 (Branson Ultrasons, Annemasse, France). The lysate was clarified by centrifugation in a Sorvall SA-600 rotor at $10,000 \mathrm{~g}$ for $30 \mathrm{~min}$ at $4{ }^{\circ} \mathrm{C}$ prior to protein purification.

\subsection{Purification and refolding}

His-tagged rLs-Stylicin1 fusion proteins were purified by affinity chromatography by incubating cell lysates with nickel-nitrilotriacetic acid resin (Novagen) at a ratio of 25:1 (v/v) in $6 \mathrm{M}$ guanidine $\mathrm{HCl}, 20 \mathrm{mM}$ Tris- $\mathrm{HCl}\left(\mathrm{pH}\right.$ 8.0) for $4 \mathrm{~h}$ at $4{ }^{\circ} \mathrm{C}$. Fusion proteins were eluted with two volumes of $6 \mathrm{M}$ guanidine $\mathrm{HCl}, 1 \mathrm{M}$ imidazole, 20mM Tris- $\mathrm{HCl}$ (pH 6.4), dialyzed against 5\% acetic acid (HOAc) in SpectraPor dialysis membranes (Spectrum Laboratories Inc., Rancho Dominguez), and lyophilized. His-tagged rLs-Stylicin1 was then loaded on a gel filtration Superdex 200 (Pharmacia) column equilibrated in 5\% acetic acid solution (flow rate of $1 \mathrm{ml} / \mathrm{min}$ ) and eluted fractions were pooled, frizzed and lyophilised. The methionine residue introduced at the rLs-Stylicin1 $\mathrm{N}$ terminus was subjected to $\mathrm{CNBr}$ cleavage by dissolving the lyophilized His-tagged fusion proteins in $50 \%$ formic acid, addition of solid $\mathrm{CNBr}$ to 10 $\mathrm{mg} / \mathrm{ml}$ (final concentration), and incubation of the mixtures for $8 \mathrm{~h}$ in the darkness at $25^{\circ} \mathrm{C}$. 
120 The cleavage reaction was terminated by adding 10 volumes of water, followed by freezing

121 and lyophilization. The cleaved fusion peptide mixture was folded at $\mathrm{pH} 8.1$ in a buffer 122 solution containing $0.1 \mathrm{M} \mathrm{NaHCO3}$ and $3 \mathrm{mM}$ reduced and $0.3 \mathrm{mM}$ oxidized glutathione in the 123 presence of $2 \mathrm{M}$ urea and 25\% $N, N$-dimethylformamide (Wu et al.,2003). Then, the folded 124 peptide mixture, rLs-Stylicin1, was resuspended in $1 \mathrm{~mL}$ of acetic acid $5 \%$ buffer then loaded 125 on a gel filtration Superdex 100 (Pharmacia) column equilibrated with the same buffer.

126 Monomeric and dimeric form of rLs-Stylicin1 fractions were isolated, lyophilised and stored 127 at room temperature. Peptide purity was analysed by Sodium Dodecyl Sulphate 128 Polyacrylamide Gel Electrophoresis (SDS-PAGE) using the Laemmli's method (Laemmli., 129 1970). Samples were prepared by heating for $10 \mathrm{~min}$ at $100^{\circ} \mathrm{C}$ in an equal volume of sample 130 buffer (0.1 M citrate-phosphate buffer, 5\% SDS, 0.9\% 2-mercaptoethanol, 20\% glycerol, pH $131 \quad 6.8)$.

\subsection{Mass spectrometry analysis}

To determine the number of cysteine residues that may be involved in the intramolecular and intermolecular disulfide bridges, mass spectrometry analysis was performed on monomeric and dimeric forms of rLs-Stylicin1. Matrix-assisted Laser Desorption/Ionisation-Time Of-Flight Mass Spectrometry (MALDI-TOF-MS) was carried out on a Bruker ULTRAFLEX mass spectrometer, set on a positive linear mode.

\subsection{Immunolocalization}

Antibodies against Ls-Stylicin1 were raised in mice (Balb/c). Briefly, 1mg of rLs-

142 Stylicin1 were coupled to ovalbumin (Sigma) in a 1: 1 mass ratio after activation with 1-ethyl143 3(3-dimethylaminopropyl) carbodiimide (Pierce). Mice (4 weeks old) received three

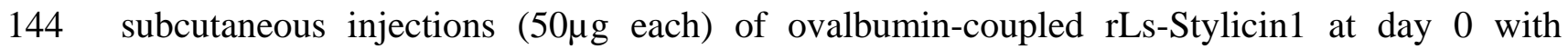


complete Freund's adjuvant, and at days 15 and 30 with incomplete Freund's adjuvant. Mouse

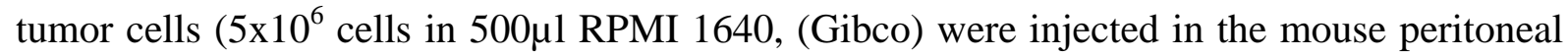
cavity at day 30. Then days after cells injection, ascitic fluid was withdrawn and clarified by centrifugation (800 X g, $15 \mathrm{~min}$ and $4^{\circ} \mathrm{C}$ ). Immunoglobulins $\mathrm{G}$ (IgG) for each sera were purified on a Hitrap protein G sepharose column using Gradifrac (Pharmacia). Reactivity and specificity of purified IgG were tested by ELISA (indirect) against rLs-Stylicin1.

L. stylirostris shrimp (20g) were obtained from French Polynesia Island. Haemolymph was taken from the ventral sinus located at the first abdominal segment, under an equal volume of anticoagulant Modified Alsever Solution (27 mM sodium citrate, $336 \mathrm{mM} \mathrm{NaCl}$, $115 \mathrm{mM}$ glucose, $9 \mathrm{mM}$ EDTA, $\mathrm{pH}$ 7) and centrifuged at $800 \mathrm{~g}$ for 15 minutes $\left(4^{\circ} \mathrm{C}\right)$ to separate the blood cells from plasma. Immunofluorescence analyses were carried out using polyclonal antibodies specific for Ls-Stylicin1, according to the method of Munoz (Munoz et al., 2004). Briefly, haemocytes, fixed with paraformaldehyde, were cytocentrifuged (900 rpm, 10 min) on L-polylysine slides. After permeabilization with $0.1 \%$ Triton X-100 (10 minutes), the haemocytes were incubated overnight $\left(4^{\circ} \mathrm{C}\right)$ with anti-Ls-Stylicin $1(2.3 \mu \mathrm{g} / \mathrm{ml})$ in PBS/Skimmed-Milk (PBS/SM) at $0.5 \%$ or irrelevant mouse IgG2a anti IgM $(3 \mu \mathrm{g} / \mathrm{ml})$ of

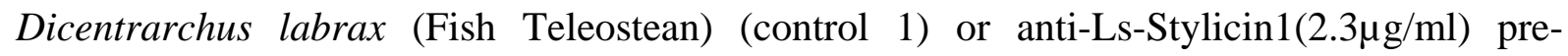
incubated with the recombinant peptide $(10 \mu \mathrm{g} / \mathrm{ml})$ (control 2). After three washes in phosphate buffer saline (PBS) a second incubation was performed for $1 \mathrm{~h}$ at room temperature with anti-mouse FITC-conjugated (Pierce) diluted at 1: $200(0.5 \mu \mathrm{g} / \mathrm{ml})$ in PBS/SM 0.5\%. Slides were washed three times in PBS, fixed with Moviol then observed by confocal microscopy (Leica TCS 4D).

\subsection{Antimicrobial assays}

The antibacterial and the antifungal activity spectrum of purified rLs-Stylicin1 was

170 investigated against a panel of Gram-positive, Gram-negative bacteria strains, fungi and yeast 
171 strains including pathogenic strains for shrimp and molluscs. Briefly, four Gram-positive

172 bacteria (Micrococcus lysodeikticus ATCC 4698; Staphylococcus aureus ATCC 25293;

173 Bacillus subtilis and Aerococcus viridans, IBMC Strasbourg collection ) and seven Gram-

174 negative bacteria (Escherichia coli 363 ATCC 11775; Salmonella typhimurium, IBMC

175 Strasbourg collection; Vibrio penaeicidae AM101; $V$. splendidus LGP32 and $V$.

176 nigripulchritudo SFn1,IFREMER collection; Pseudomonas aeruginosa and Enterococcus

177 faecalis, LIBRAGEN collection, Toulouse), were used in a liquid growth inhibition assay

178 (Destoumieux et al., 1997). In brief, 10 $\mu \mathrm{L}$ of rLs-Stylicin1 dilutions were incubated in 96-

179 well microtiter plates with $100 \mu \mathrm{l}$ of bacteria suspension, starting at OD $600 \mathrm{~nm}=0.001$, in

180 Poor Broth nutrient medium (1\% bactotryptone, 0.5\% (w/v) NaCl, $\mathrm{pH}$ 7.5). Bacterial growth

181 was assayed by measuring $\mathrm{OD}_{600 \mathrm{~nm}}$ after $24 \mathrm{~h}$ incubation from $20^{\circ} \mathrm{C}$ to $37^{\circ} \mathrm{C}$ according to the

182 optimal grow temperature of each bacteria. The minimal inhibitory concentration (MIC) was

183 evaluated by testing serial replica dilutions, defined as the lowest peptide concentration that

184 prevents any growth (Hancock et al., 1995). The Minimal Bactericidal Concentration (MBC)

185 was determined as the lowest concentration that kills $99.9 \%$ of bacteria.

186 Susceptibility of Fusarium oxysporum (a gift from A. Vey, INRA Saint Christol-lez-

187 Alès, France), Penicillium sp and Botrytis cinerae (fungi collection, IUT Department Génie

188 Biologique, Montpellier), Aspergillus fumigatus, Neurospora crassa and Candida albicans

189 (LIBRAGEN collection, Toulouse) were tested by a Fehlbaum modified liquid growth

190 inhibition assay (Fehlbaum et al., 1994). In brief, fungal spores $100 \mu$ l final concentration $10^{4}$

191 spores $\mathrm{mL}^{-1}$ were suspended in a Potatoes Dextrose Broth (Difco) complemented with

192 tetracycline $(10 \mu \mathrm{g} / \mathrm{ml}$ final concentration) and $10 \mu \mathrm{L}$ of rLs-Stylicin1 dilutions in microtiter

193 plates. Peptide was replaced by $10 \mu \mathrm{l}$ of sterile water in controls. Growth inhibition was

194 observed under the microscope after 24 or $48 \mathrm{~h}$ incubation at $30^{\circ} \mathrm{C}$ and quantified by OD 600 
195

196

197

198

199

200

201

202

203

204

205

206

207

208

209

210

211

212

213

214

215

216

217

218

219

nm measurement after $48 \mathrm{~h}$. The Minimal Inhibitory Concentration (MIC) was defined as described above.

\subsection{Binding and agglutination assays}

The binding of rLs-Stylicin1 to $V$. penaeicidae AM101 was examined. Briefly, an overnight culture of fresh cells was prepared. Cells were washed twice with PBS and centrifuged (1000 rpm, $30 \mathrm{~min}$ at room temperature) to eliminate the culture media. Cells were suspended in $1 \mathrm{ml}$ PBS $\left(1 \times 10^{7}\right.$ cells $\left./ \mathrm{ml}\right)$ and rLs-Stylicin 1 added at a concentration of $10 \mu \mathrm{g} / \mathrm{ml}$ in PBS. Peptides were substituted with PBS for the control. The mix was incubated for two hours at $4^{\circ} \mathrm{C}$ then washed 3 times with PBS. Mouse anti rLs-Stylicin1 IgG (laboratory product) was added $(10 \mu \mathrm{g} / \mathrm{ml}$ in $\mathrm{PBS} / \mathrm{SM} 0.5 \%)$ for $1 \mathrm{~h}$ at $37^{\circ} \mathrm{C}$ then washed 3 times in PBS. FITC-conjugated anti-mousse IgG (Pierce Interchim) diluted 500 fold $(2 \mu \mathrm{g} / \mathrm{ml})$ in PBS/SM 0.5\%, was added for $1 \mathrm{~h}$ at $37^{\circ} \mathrm{C}$. Cells were washed three times in PBS and, after fitting with glycerine buffer, were observed by fluorescence microscopy.

The quantitative binding assay of rLs-Stylicin1 to LPS was determined by an enzymelinked immunosorbent assay (ELISA) using the anti-rLs-Stylicin1 antibody prepared as described previously. A microtiter plate was coated with $50 \mu \mathrm{l}$ of $5 \mu \mathrm{g} / \mathrm{ml}$ E. coli 0127:B8 LPS (SIGMA) and V. penaeicidae LPS (Lab purification using the Bligh and Dyer method; Blight \& Dyer, 1959) in $0.1 \mathrm{M} \mathrm{Na}_{2} \mathrm{CO}_{3}, 20 \mathrm{mM}$ EDTA, pH 9.6, for $3 \mathrm{~h}$ at $50 \mathrm{C}$. The plate was washed twice with PBS and then blocked with 5\% (w/v) BSA in PBS buffer for 1 h at room temperature and subsequently incubated with various amounts of purified rLs-Stylicin1 (0 $16.8 \mu \mathrm{M}$ ) for $1 \mathrm{~h}$ at room temperature. Control was the wells without rLs-Stylicin1 incubation. The plate was washed as above and then incubated with $50 \mu \mathrm{l}$ of $10 \mu \mathrm{g} / \mathrm{ml}$ mouse anti rLsStylicin1 IgG in $0.1 \%(\mathrm{w} / \mathrm{v})$ BSA/PBS for $2 \mathrm{~h}$ at $37 \mathrm{C}$. After washing as above the plate was incubated with an horseradish peroxidase-conjugated anti-mouse IgG (Pierce Interchim) 
220 (1:5000 dilution, $0.2 \mu \mathrm{g} / \mathrm{ml})$ in $0.1 \%(\mathrm{w} / \mathrm{v})$ BSA/PBS for $1 \mathrm{~h}$ at room temperature, washed 221 again and developed with orthophenylenediamine in substrate buffer $(0.1 \mathrm{~m}$ citric acid, $0.1 \mathrm{M}$ 222 sodium acetate, $\mathrm{pH} 5.4$ containing $0.33 \% \mathrm{H}_{2} \mathrm{O}_{2}$ ). The reaction was stopped after 15 min by 223 adding $50 \mu \mathrm{l}$ of $4 \mathrm{~N} \mathrm{H}_{2} \mathrm{SO}_{4}$ and the plate was analyzed in a microtiter plate reader Multiskan Ex 224 Labsystems at $490 \mathrm{~nm}$. Experiments were performed in one independent repeat in triplicate 225 for statistical analyses. The apparent dissociation constants $\left(K_{\mathrm{d}}\right)$ and the maximum binding $226\left(A_{\max }\right)$ parameters were calculated with KaleidaGraph for Windows, Software, using 227 nonlinearly fitting as $A=A_{\max }[\mathrm{L}] /(K \mathrm{~d}+[\mathrm{L}])$, where $A$ is the absorbance at $490 \mathrm{~nm}$ and $[\mathrm{L}]$ is the 228 ligand concentration.

The agglutination of $V$. penaeicidae bacteria by rLs-Stylicin1 was considered. Briefly, $20 \mu \mathrm{l}$ of $V$. penaeicidae fresh cells $\left(1 \times 10^{8}\right.$ cells $\left./ \mathrm{ml}\right)$ were mixed with $10 \mu \mathrm{L}$ of $160 \mu \mathrm{M}$ peptide solution in PBS. The mixture was then incubated for 1 hour at $37^{\circ} \mathrm{C}$ and the agglutination observed by optical microscopy. Peptides were substituted with PBS for the control.

\section{Results}

\subsection{Sequence analysis}

Nucleic sequences of Ls-stylicin1 were cloned from the haemocytes of L. stylirostris.

237 The Ls-Stylicin1 cDNA sequence (GenBank accession no. EU177435) was 325 bp-long (Fig. 238 1). The corresponding genomic sequence (GenBank accession no. EU177436) obtained by 239 PCR-amplification was 525 bp-long. Sequence analysis of the Ls-Stylicin1 gene showed that 240 it is composed of two exons and one intron (213 bp) inserted between nucleotide 77 and 241 nucleotide 78 of the cloned cDNA sequence (Fig. 1). The coding sequence was compared 242 with sequences available in Genbank databases (NCBI) using the BLASTn and BLASTx 243 network service. It revealed more than $80 \%$ sequence similarity with several sequences from penaeid shrimp: these include cDNA sequences from L. stylirostris (GenBank accession nos. 


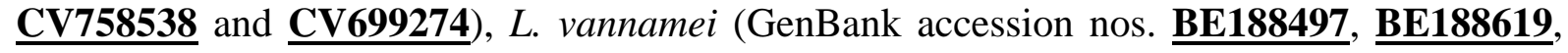

246 BE188495, $\underline{\text { CK591498, }}$ CK591516, $\underline{\text { CK591492, }}$ and $\underline{\text { CV468241) }}$, Penaeus monodon

247 (GenBank accession nos. $\underline{\text { DW042940 }}$ and $\underline{\text { DW678039)}}$ ) and two genomic sequences from $L$.

248 stylirostris (GenBank accession no. EU177436 and $\underline{\text { EU177437). }}$

249 The amino acid sequence deduced from Ls-stylicin1 cDNA is 104 residues long (Fig.

250 1). It has a predicted 22 amino acid signal peptide from $\mathrm{Met}^{1}$ to $\mathrm{Gly}^{22}$, as determined by Van

251 Heijne’s rules (Nielsen et al., 1997), and a putative Lys ${ }^{98}$-Lys ${ }^{99}$ prohormone convertase site in

252 its C-terminal sequence. The predicted mature Ls-stylicin1 is therefore an 82 amino acid

253 peptide, starting from Ser $^{23}$ and ending at Gly ${ }^{104}$, which is determined to be anionic with a

254 calculated pI of 5.00. Sequence analysis of the mature Ls-Stylicin1 revealed the presence of

25516 proline residues representing $19.5 \%$ of the whole sequence. Those proline residues are

256 concentrated in the N-terminal. Besides, Ls-Stylicin1 contains 13 cysteine residues

257 representing $15.9 \%$ of the whole sequence, which are present in the C-terminal part of the

258 molecule (Fig. 1). No whey acidic protein (WAP) domain, lectin amino-acid motifs (CTLD),

259 ligand-binding (QPD) motifs or potential glycosylation site were identified in the Ls-Stylicin1

260 amino acid sequence.

261 Translated sequences identified previously revealed five peptides sequences from 262 penaeid shrimps, two from $L$. stylirostris, two partial sequences from L. vannamei and one 263 partial sequence from P. monodon (Fig. 2). Moreover, compared with peptidic sequences 264 available in Genbank data bases (NCBI) using the BLASTp network service, no significant 265 sequence homology was found with antimicrobials, cysteine-rich, proline-rich peptides or any 266 other well characterized peptides. Altogether, this suggests that Ls-Stylicin1 is the first 267 member of a novel family of peptides from penaeid shrimp. 


\subsection{Recombinant expression of Ls-Stylicin 1 in $E$. coli and purification}

The 82 amino-acid recombinant peptide, rLs-Stylicin1, corresponds to the deduced mature peptide sequence, Ser $^{23}-$ Gly $^{104}$ of the Ls-Stylicin1 studied here (Fig. 1). The rLsStylicin1 produced in the heterologous expression system (pET-28b (+) vector) and folded, appeared as a monomer form with a molecular mass of $8.9 \mathrm{kDa}$ (Fig 3A) and multimeric forms (Fig. 3B) as revealed by non reducing gel electrophoresis. The two major forms, monomer and dimer, were purified by gel filtration chromatography. The homogenous preparation of monomer (Fig. 3A) was mass measured at 8920.40 Daltons by MALDI-TOF MS (Fig. 3C). In comparison to the calculated mass of 8932.20 Daltons, the 11.80 Dalton losses may correspond to the mass of 12 hydrogen elements coming from 12 of the 13 cysteine residues present in the molecule and implicated in disulfide bridge formation.

The second homogenous preparation of homodimer was mass measured at 17838.81 Daltons by MALDI-TOF MS (Fig. 3D). In comparison to the calculated mass of 17864.40 Daltons (dimer with 1 disulfide bridge cross-linkage), the 25.59 Daltons loss in mass corresponds to the mass of 26 hydrogen elements coming from 24 residues of cysteine implicated in monomeric disulfide bridges formation and from 2 residues may implicated in cross link formation of homodimer.

\subsection{Ls-Stylicin1 localization in haemocytes}

The peptide localization within haemocytes was investigated by indirect immunofluorescence using specific antibodies. Immunofluorescence assays showed a strong immunolabelling for all the haemocyte populations (Fig. 4A, right and left panel) including hyaline and granular cells, as evidenced on the same view observed by light microscopy. Moreover, Ls-Stylicin1 appears to be localized in small cytoplasmic granules of the haemocytes. No fluorescence was observed on haemocytes incubated with irrelevant mouse 
IgG2a anti IgM of Dicentrarchus labrax. (Fig. 4B) or anti-rLs-Stylicin1 pre-incubated with rLs-Stylicin1 peptide (Fig. 4C).

\subsection{Antimicrobial activities}

The monomer form displays weak bacteriostatic activity (up to 4 times the MIC) against Vibrio species, particularly the shrimp pathogenic strains $V$. penaeicidae and $V$. nigripulchritudo, with MIC values from $40 \mu \mathrm{M}$ to $80 \mu \mathrm{M}$ (Tab. 1). Otherwise, no activity against other Gram-negative or Gram-positive bacteria tested was detected up to concentrations of $160 \mu \mathrm{M}$. Among the six fungal and yeast species tested, antifungal activity was observed against the filamentous shrimp pathogen, $F$. oxysporum with both monomeric and dimeric forms (Tab. 1) (Souheil et al., 1999). In addition, we noted that, at concentrations of $2.5 \mu \mathrm{M}$ (the MIC) F. oxysporum spore germination was inhibited but with no abnormal morphology. Otherwise, no activity against Penicillium sp, B. cinerae, A. fumigatus, $N$. crassa, or C. albicans was detected up to peptide concentrations of $100 \mu \mathrm{M}$.

Interestingly, similar antimicrobial effects were observed with the dimer, a bacteriostatic effect against Vibrio sp and an antifungal effect against $F$. oxysporum at the peptide concentrations of $20 \mu \mathrm{M}$ and $1.25 \mu \mathrm{M}$ respectively.

\section{5. $V$. penaeicidae binding assays}

To assay the binding of rLs-Stylicin1 to V. penaeicidae, bacteria were incubated with rLs-Stylicin1 and stained with anti-Ls-Stylicin1 IgG followed by FITC-conjugated anti-mouse IgG immunostaining. Immunofluorescence assays showed a strong labelling of bacteria was observed (Fig. 5A). The ability of rLs-Stylicin1 to bind $V$. penaeicidae cells was therefore investigated. To determine the potential agglutination properties of rLs-Stylicin1, fresh cells of $V$. penaeicidae were incubated with increasing concentration of rLs-Stylicin1. Bacteria 
agglutination was observed by light microscopy after 1 hour incubation at $37^{\circ} \mathrm{C}$ with highly concentrated rLs-Stylicin1 (160 $\mu \mathrm{M})$ (Fig. 5C).

Because Ls-Stylicin1 may bind to the cell surface components of Gram-negative bacteria, we tested LPS as a candidate ligand for rLs-Stylicin1. To measure binding of rLsStylicin1 to LPS, we performed an enzyme-linked immunosorbent assay in which the LPS from $V$. penaeicidae or E. coli (O127:B8) was coated onto a microplate. We showed that rLsStylicin1 binds to both LPSs in a concentration-dependent manner (Fig. 6). Nonlinear regression analysis with a one site binding model $\left(0.93<R^{2}<0.96\right)$ revealed that rLsStylicin1 bound to $V$. penaeicidae and E. coli LPS with an apparent dissociation constant $\left(K_{\mathrm{d}}\right)$ of 0.096 and $0.102 \mu \mathrm{M}$, respectively.

\section{Discussion}

In this study we report the characterization of Ls-Stylicin1, a novel antimicrobial peptide from the penaeid shrimp, L. stylirostris. The nucleotide and deduced amino-acid sequences of the Ls-Stylicin1 showed high sequence similarities (80\%) to unknown peptides from penaeid shrimp previously deposited in Genbank. All sequences contain a highly similar proline-rich region at the N-terminus and similar C-terminal cysteine-rich region. Such structural are also characterized of penaeidins, a family of antimicrobial peptides from penaeid shrimp (Bachere et al., 2000; Gueguen et al., 2006). However, no sequence similarity, no conserved WAP domain, lectin amino-acid motifs (CTLD), ligand-binding (QPD) motifs, or known PRP motifs was found between Ls-Stylicin1 and other antimicrobial peptides well characterized up to now. Therefore Ls-Stylicin1 was proposed to be the first member of a new family of peptides present in penaeid shrimp.

The recombinant Ls-Stylicin1 was first investigated for its potential antimicrobial activities. The peptide proved to be poorly antibacterial with MICs in the range of 40 to 80 
$\mu \mathrm{M}$. Because those MICs are rather high, we speculated that a direct antibacterial activity

346 such as the typical membrane disruption was unlikely. Moreover, the peptide displays a 347 negative net charge at a physiological $\mathrm{pH}$ and is rather anionic in contrast with most of the 348 antimicrobial peptides identified so far.

Besides, rLs-Stylicin1 is active against Vibrio sp with bacteriostatic activity. We therefore hypothesized that the mechanism of bacterial growth inhibition could rely on the 351 ability of rLs-Stylicin1 to bind Gram-negative bacteria and their cell walls. From those 352 binding assays, rLs-Stylicin1 appeared to function as a pattern recognition protein, especially through its interaction with LPS present in cell wall of Gram-negative bacteria, and more particularly LPS from V. penaeicidae. Indeed, the rLs-Stylicin1 strongly bound to 355 immobilized LPS of both $V$. penaeicidae and E. coli with a dissociation constant (Kd) of $3560 ; 96 \times 10^{-7}$ and $1.02 \times 10^{-7} \mathrm{M}$, respectively. The binding constants of rLs-Stylicin 1 for LPS are 357 in agreement with the values obtained with other known binding proteins, such as polymyxine B, human CD14 (Kirkland et al., 1993), the limulus factor C (Tan et al., 2000), the 359 Crassostreas gigas BPI (Gonzalez et al., 2007) or Penaeus monodon rALFPm3 360 (Somboonwiwat et al., 2008), which range from $3.3 \times 10^{-7} \mathrm{M}$ to $2.3 \times 10^{-10} \mathrm{M}$. This strongly 361 suggests that LPS is one of the target molecules for Ls-Stylicin1. It is tempting to speculate 362 that the proline-rich region of rLs-Stylicin1 could be implicated in the LPS binding as 363 reported for other antibacterial peptides (Gennaro et al., 2002; Li et al., 2006; Cuthbertson et 364 al., 2004) and, like peneidins, in bacterial aggregation, rather than in direct bacterial killing 365 (Munoz, 2002). On that basis, we hypothesize that the antibacterial activities are the result of 366 a combination of rLs-Stylicin1 LPS-binding and rLs-Stylicin1 multimerization processing. 367 This is supported by our experimental data showing a bacteriostatic activity observed at low 368 peptide concentration as well as in vitro agglutination at high peptide concentration, when 369 rLs-Stylicin1 multimerization is likely to occur. Such agglutination may also occur in vivo 
thereby facilitating the haemocyte-mediated bacterial clearance. Beyond that, the whole process may help to protect shrimp from $V$. penaeicidae infections.

While poorly antimicrobial, Ls-Stylicin1 proved to be strongly active against the filamentous fungus pathogenic for shrimp $F$. oxysporum $(\mathrm{MIC}=2.5 \mu \mathrm{M})$. Other cysteine-rich peptides that exhibit antifungal activity have been previously characterized. All these peptides display a conserved pairing of six cysteine residues such as the shrimp penaeidins (Bachere et al., 2000), the potatoes Snakin1 (Segura et al., 1999) or the horse shoe crab Tachycitin (Kawabata et al., 1996; Suetake et al., 2002). Moreover they are cationic and display chitinbinding activity. The molecule described here has no conserved pairing of six cysteine residues; it is anionic and does not bind chitin (data not show). So it can hardly be compared with earlier described antifungal peptides. Based on its antifungal activity, Ls-Stylicin1 could bind molecules of F. oxysporum cell wall and affect the fungi grow. Proteins that bind both LPS (as Ls-Stylicin1) and fungi cell wall molecules such as the $\beta 1-3$ glucan (schoffelmeer et al., 1999) have been previously described in penaeid shrimps. They are referred to as the lipopolysaccharides / $\beta 1$-3-glucan binding proteins (LGBP) from P. stylirostris (Roux et al., 2002), from $P$. monodon (Sritunyalucksana et al., 2002) and from $P$. vannamei (Romo-Figueroa et al., 2004). Moreover, the antifungal activity of this peptide was comparable to the C-terminal fragment of Hemocyanin PvHCt, an anionic peptide (theorical $\mathrm{pI}=6.04$ ) strictly anti-fungal, with MIC value from 3 to $50 \mu \mathrm{M}$ (Destoumieux et al 2001). Given that no structure homology is found between rLs-Stylicin1 and PvHCt. The negative charge of both peptides at physiological $\mathrm{pH}$ may play an important role in their anti-fungal activities.

Monomer and dimer of Ls-Stylicin1 exhibits similar antimicrobial activity spectrum, suggesting that the antimicrobial activity of rLs-stylicin1 is independent of its tertiary structure. Those results are consistent with the previously described antimicrobial peptide, the 
395

396

397

398

bactenecin. Indeed, both form of this peptide are demonstrated to completely kill both Staphylococcus aureus and E. coli at concentration of $8 \mu \mathrm{M}$. However, unlike the monomer, the homodimer of bactenecin displayed membrane-lytic activity and consequently has more potent antibacterial activity than the monomer at physiological conditions (Lee et al., 2009). The same probably does not apply to Ls-Stylicin1, since Ls-Stylicin1 homodimer have a bacteriostatic effect on bacteria. Future studies will help understanding the role of stylicin multimerization in shrimp defense.

Tissue-specific expression analysis of Ls-Stylicin1 in adult L. stylirostris shrimp revealed that this peptide is expressed and localized in haemocytes. Moreover, it has been previously demonstrated that the corresponding mRNA was over-expressed in the haemocyte of L. stylirostris shrimp surviving an experimental infection with V. penaeicidae (de Lorgeril et al., 2005). This suggests that Ls-Stylicin1 is abundantly produced in hemocytes of shrimp surviving a $V$. penaeicidae challenge. The shrimp immune response to infection involves massive hemocyte recruitment to infection sites where penaeidins are released (Munoz et al., 2004). There, like penaeidins, Ls-stylicins could participate to the isolation and elimination of the bacteria. The presence of a signal peptide support the hypothesis of Ls-Stylicin1 release. Alternatively, Ls-Stylicin1 facilitates the intracellular elimination of pathogens by phagocytes through a potential opsonic effect, base on the LPS-binding activity of stylicins. This potential involvement in defense reaction through binding to pathogens deserves further investigation.

In conclusion, as presented in the results section, several stylicin-like peptides are present in the public EST databases, all of them being found in penaeid shrimp. Moreover, we have identified a second Stylicin coding cDNA sequence from L. stylirostris (data not shown). Together with the experimental data from this article, this indicates that Ls-Stylicin1 is the 
419 first member of a new family of antimicrobial peptides from penaeid shrimp, and primarily 420 active against pathogenic filamentous fungi.

421 


\section{References}

Aguirre-Guzman, G., Sanchez-Martinez, JG., Campa-Cordova, AI., Luna-Gonzalez, A., Ascencio, F., 2009. Penaeid Shrimp Immune System. Thai. J. Vet. Med. 39(3), 205-215.

Amparyup, P., Kondo, H., Hirono, I., Aoki, T., Tassanakajon, A., 2008. Molecular cloning, genomic organization and recombinant expression of a crustin-like antimicrobial peptide from black tiger shrimp Penaeus monodon. Mol. Immunol. 45(4), 1085-1093.

Bachère, E., Destoumieux, D., \& Bulet, P., 2000. Penaeidins, antimicrobial peptides of shrimp: a comparison with other effectors of innate immunity. Aquaculture. 191(1-3), 71-88.

Bachère, E., Gueguen, Y., Gonzalez, M., De Lorgeril, J., Garnier, J and Romestand, B., 2004. Insights into the antimicrobial defense of marine invertebrates : the penaeid shrimps and the oyster Crassostrea gigas. Immunological reviews 198, 149-168.

Bartlett, TC., Cuthbertson, BJ., Shepard, EF., Chapman, RW., Gross, PS., Warr, GW., 2002. Crustins, homologues of an 11.5-kDa antibacterial peptide, from two species of penaeid shrimp, Litopenaeus vannamei and Litopenaeus setiferus. Mar. Biotechnol (NY). 4(3), 278-9.

Bligh, EG and Dyer, WJ., 1959. A rapid method of total lipid extraction and purification. Can. J. Biochem. Physiol. 37(8), 911-917.

Cuthberson, B.J., Bullesbach, E.E., Fievet, J., Bachère, E., \& P.E, Gross., 2004. A new class (penaeidin class 4) of antimicrobial peptides from the Atlantic white shrimp (Litopenaeus setiferus) exhibits target specificity and an independent proline-richdomain function. J. Biochem. 381, 79-86.

De Lorgeril, J., Saulnier, D., Janech, M.G., Gueguen, Y., Bachere, E., 2005. Identification of genes that are differentially expressed in hemocytes of the Pacific blue shrimp 
(Litopenaeus stylirostris) surviving an infection with Vibrio penaeicidae. Physiol. Genomics. 21(2), 174-183.

448

449

450

451

452

453

454

455

456

457

458

459

460

461

462

463

464

465

466

467

468

469

470

Destoumieux, D., Bulet, P., Loew, D., VanDorsselaer, A., Rodriguez, J., Bachère E., 1997. Penaeidins, a new family of antimicrobial peptides isolated from the shrimp Penaeus vannamei (Decapoda). J. Biol. Chem. 272(45), 28398-28406.

Destoumieux, D., Munoz, M., Bulet, P., Bachere, E., 2000. Penaeidins, a family of antimicrobial peptides from penaeid shrimp (Crustacea, Decapoda). Cell. Mol. Life. Sci. 57(8-9), 1260-1271.

Destoumieux-Garzon, D., Saulnier, D., Garnier, J., Jouffrey, C., Bulet, P., Bachere, E., (2001). Crustacean immunity - Antifungal peptides are generated from the $C$ terminus of shrimp hemocyanin in response to microbial challenge. J. Biol. Chem. 276(50), 4707047077.

Fehlbaum, P., Bulet, P., Michaut, L., Lagueux, M., Broekaert, W.F. Hetru., C. \& Hoffmann, J.A., 1994. Insect immunity, Septic injury of drosophila induces the synthesis of apotent antifungal peptide with sequence homology to plant antifungal peptides. J. Biol. Chem. 269, 33159-33163.

Gennaro, R., Zanetti, M., Benincasa, M., Podda, E., Miani, M., 2002. Pro-rich antimicrobial peptides from animals: Structure, biological functions and mechanism of action. Curr. Pharm. Des. 8(9), 763-778.

Gonzalez, M., Gueguen, Y., Destoumieux-Garzon, D., Romestand, B., Fievet, J., Pugniere, M., Roquet, F., Escoubas, JM., Vandenbulcke, F., Levy, O., Saune, L. Bulet., P.and Bachere (2007) Evidence of a bactericidal permeability increasing protein in an invertebrate, the Crassostrea gigas Cg-BPI. Proc.Natl.Acad. Sci. 104(45), 17759-17764.

Gueguen, Y., Garnier, J., Robert, L., Lefranc, MP., Mougenot, I., de Lorgeril, J., Janech, M., Gross, PS., Warr, GW., Cuthbertson, B., Barracco, MA., Bulet, P., Aumelas, A., Yang, 
YS., Bo, D., Xiang, JH., Tassanakajon, A., Piquemal, D., Bachere, E., 2006. PenBase, the shrimp antimicrobial peptide penaeidin database: Sequence-based classification and recommended nomenclature. Dev. Comp. Immunol. 30(3), 283-288.

Hancock, R.E., Falla, T., \& Brown, M., 1995. Cationic bactericidal peptides. Adv. Microb. Physiol. 37, 135-175.

Higgins, D.G., Bleasby, A.J., \& Fuchs, R., 1992. CLUSTAL V: Improved software for multiple sequence alignment. Comput. App. Bios. 8(2), 189-191.

Kawabata, S., Nagayama, R., Hirata, M., Shigenaga, T., Agarwala, KL., Saito, T., Cho, JK., Nakajima, H., Takagi, T., Iwanaga, S., 1996. Tachycitin, a small granular component in horseshoe crab hemocytes, is an antimicrobial protein with chitin-binding activity. $J$. Biochem. 120 (6), 1253-1260.

Kirkland, TN., Finley, F., Leturcq, D., Moriarty, A., Lee, JD., Ulevith, RJ., Tobias, 1993. Analysis of lypopolysaccharide binding by CD14. J. Biol. Chem: 268 (33), 2481824823.Laemmli U.K., 1970. Cleavage of structural proteins during the assembly of the head bacteriophage T4. Nature. 227, 680-685.

Li, W.F., Ma, G.X., Zhou, X.X., 2006. Apidaecin-type peptides: Biodiversity, structurefunction relationships and mode of action. Peptides. 27(9), 2350-2359

Lee, JY., Yang, ST., Kim, HJ., Lee, SK., Jung, HH., Shin, SY., Kim, JI.,(2009). Different modes of antibiotic action of homodimeric and monomeric bactenecin, a cathelicidinderived antibacterial peptide. BMB. Rep. 42(9), 586-592.

Luo, T., Yang, H., Li, F., Zhang, X., Xu, X., 2006. Purification, characterization and cDNA cloning of a novel lipopolysaccharide-binding lectin from the shrimp Penaeus monodon. Dev. Comp. Immunol. 30(7), 607-617.

Mai, WJ., Hu, CQ., 2009. cDNA cloning, expression and antibacterial activity of lysozyme C in the blue shrimp (Litopenaeus stylirostris). Prog. Nat. Sci. 19(7), 837-844. 
Medzhitov. R., Janeway. C.A., 2002. Decoding the patterns of self and nonself by the innate immune system. Science. 296, 298-300.

Munoz, M., 2002. Penaeidins, family of antimicrobial peptides from crustaceans : implication and function in the immune response of penaeid shrimps (Crustacea, decapoda). Thesis UPMC, Paris.

Munoz, M., Vandenbulcke, F., Garnier, J., Gueguen, Y., Bulet, P., Saulnier, D., Bachère, E., 2004. Involvement of penaeidins in defense reactions of the shrimp Litopenaeus stylirostris to a pathogenic vibrio. Cell. Mol. Life. Sci. 61, 961-972.

Nielsen, H., Engelbrecht, J., Brunak, S., vonHeijne, G., 1997. Identification of prokaryotic and eukaryotic signal peptides and prediction of their cleavage sites. Protein. Eng. 10(1), 1-6.

Romo-Figueroa,MG., Vargas-Requena, C., Sotelo-Mundoa, RR., Vargas-Albores, F., Higuera-Ciapara, I., Soderhall, K., Yepiz-Plascencia, G.,(2004). Molecular cloning of a beta-glucan pattern-recognition lipoprotein from the white shrimp Penaeus (Litopenaeus) vannamei: correlations between the deduced amino acid sequence and the native protein structure. Dev. Comp. Immunol. 28(7-8), 713-726.

Roux, MM., Pain, A., Klimpel, KR., Dhar ,AK., (2002). The lipopolysaccharide and beta-1,3glucan binding protein gene is upregulated in white spot virus-infected shrimp (Penaeus stylirostris). J. Virol. 76(14), 7140-7149.

Schoffelmeer, EAM., Klis, FM., Sietsma, JH., Cornelissen, BJC., (1999). The cell wall of Fusarium oxysporum. Fungal. Genet. Biol. 27(2-3), 275-282.

Segura, A., Moreno, M., Madueno, F., Molina, A., Garcia-Olmedo, F., 1999. Snakin-1, a peptide from potato that is active against plant pathogens. Mol. Plant. Microbe. Interact. 12(1), 16-23. 
Somboonwiwat, K., Bachere, E., Rimphanitchayakit, V., Tassanakajon, A., 2008. Localization of anti-lipopolysaccharide factor (ALFPm3) in tissues of the black tiger shrimp, Penaeus monodon, and characterization of its binding properties. Dev Comp Immunol. 32(10), 1170-1176.

\section{4}

http://bioinfo.genopole-toulouse.prd.fr/multalin/multalin.html (Bate). Aquaculture. 178 (3-4), 209-224. 769.

Wiley, J \& Sons, inc., 2003. Current Protocols in Molecular Biology. 14.

Souheil, H., Vey, A., Thuet, P., Trilles, J.P., 1999. Pathogenic and toxic effects of Fusarium oxysporum (Schlecht.) on survival and osmoregulatory capacity of Penaeus japonicus

Sritunyalucksana, K., Lee, SY., Soderhall, K., (). A beta-1,3-glucan binding protein from the black tiger shrimp, Penaeus monodon. Dev. Comp. Immunol. 26(3), 237-245.

Suetake, T., Aizawa, T., Koganesawa, N., Osaki, T., Kobashigawa, Y., Demura, M., Kawabata, S., Kawano, K., Tsuda, S., Nitta, K., 2002. Production and characterization of recombinant tachycitin, the Cys-rich chitin-binding protein. Protein. Eng. 15 (9), 763-

Tan, NS., Ho, B., Ding, JL., 2000. High-affinity LPS binding domain(s) in recombinant factor C of a horseshoe crab neutralizes LPS-induced lethality. The FASEB Journal. 14, 859870.Von Horsten, HH., Schäfer, B., Kirchhoff, C., 2004. SPAG11/isoform HEX, an atypical anionic beta-defensin-like peptide Source. Peptides. 25(8), 1223-1233.

Zhang, J., Li, F., Wang, Z., Xiang, J., 2007. Cloning and recombinant expression of a crustinlike gene from Chinese shrimp, Fenneropenaeus chinensis. J. Biotechnol. 127(4), 605- 
545 Fig. 1. Ls-Stylicin1 cDNA sequence (EU177435, 312 bp) and deduced peptide (104 amino 546 acids). The start and stop codons are shown in bold. The 22 amino acid signal peptide 547 sequence is indicated by a solid underline. Putative proline rich region is indicated in tight 548 region. Conserved cysteine residues are marked with $\boldsymbol{\Delta}$. Lysine-lysine prohormone 549 convertases site is marked with $\mathbf{m}$. Sequence and position of the intron(213 bp) from the 550 corresponding genomic sequence (EU177436) are indicated by a box.

551

552 Fig. 2. Alignment of consensus translated sequences find in GeneBank Database. Ls-Stylicin1

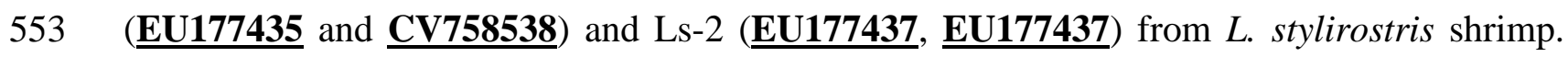

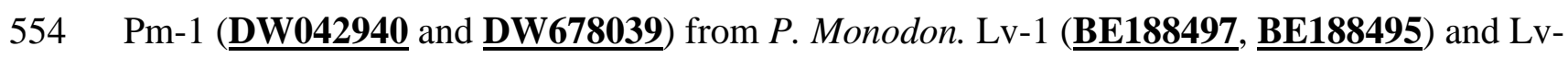
5552 (K591498, $\underline{\text { CV468241, }}$ CK591492) partial sequences from L. vannamei shrimp. Variant 556 amino acids are indicated in black regions.

Fig. 3. SDS-PAGE Tris-Tricine analysis of the purified rLs-Stylicin1. Purified monomer (A, lane 1) and multimer (B, lane1). Lane $\mathrm{M}$ is the molecular weight marker. MALDI-TOF MS spectra of the purified monomer (C) and dimer (D).

Fig. 4. Immunolocalization of rLs-Stylicin1 peptide in hemocytes. L. stylirostris hemocytes + anti-rLs-Stylicin1(A); L. stylirostris hemocytes + irrelevant mouse IgG2A anti IgM of Dicentrarchus labrax (B). L. stylirostris hemocytes+ anti-rLs-Stylicin1 pre-incubated with rLs-Stylicin1 (C). Granular cell (G), Hyaline cell (H).

566 Fig. 5. Immunofixation of rLs-Stylicin1 peptide on $V$. penaeicidae (Vp) membrane observed 567 under a fluorescence microscope (40x). V. penaeicidae + rLs-Stylicin1 + anti- rLs-Stylicin1 
IgG (A); V. penaeicidae + anti- rLs-Stylicin1 IgG (negative control) (B). Agglutination of $V$.

569 penaeicidae observed under optical microscope in presence of highly concentrate rLs570 Stylicin1 (C); V. penaeicidae negative control (D).

571

572 Fig. 6. Quantitative binding of rLs-Stylicin1 to immobilized LPS. The microtiter plates were

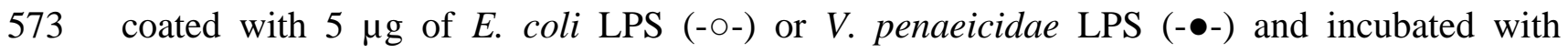
574 increasing concentration of purified rLs-Stylicin1 in Tris buffer containing $0.1 \mathrm{mg} / \mathrm{ml} \mathrm{BSA.}$ 575 Bond rLs-Stylicin1 was detected using purified mouse anti rLs-Stylicin1 antibodies as 576 described under "Experimental Procedures." Each point represents the mean of three 577 individual measurements \pm S.E. In the second graph, the lines represents the corresponding 578 curves calculated for one-site binding $\left(R^{2}=0.97\right)$. 
Tab. 1.

MIC ( $\mu \mathrm{M})$

\begin{tabular}{|c|c|c|}
\hline \multirow{4}{*}{$\begin{array}{l}\operatorname{Gram}(+) \\
\text { bacteria }\end{array}$} & Micrococcus lysodeikticus & $>160$ \\
\hline & Staphylococcus aureus & $>160$ \\
\hline & Bacillus subtilis & $>160$ \\
\hline & Aerococcus viridans & $>160$ \\
\hline \multirow{7}{*}{$\begin{array}{l}\text { Gram (-) } \\
\text { bacteria }\end{array}$} & Enterococcus faecalis & $>160$ \\
\hline & Pseudomonas aeruginosa & $>160$ \\
\hline & Escherichia coli 363 & $>160$ \\
\hline & Salmonella typhimurium & $>160$ \\
\hline & Vibrio splendidus LGP32 & $\mathbf{8 0}$ \\
\hline & Vibrio penaecidae* & 40 \\
\hline & Vibrio nigripulchritudo* & 80 \\
\hline \multirow{6}{*}{$\begin{array}{l}\text { Fungi and } \\
\text { yeast }\end{array}$} & Fusarium oxysporum* & 2.5 \\
\hline & Penicillium spp & $>100$ \\
\hline & Botrytis cinerae & $>100$ \\
\hline & Aspergillus fumigatus & $>100$ \\
\hline & Neurospora crassa & $>100$ \\
\hline & Candida albicans & $>100$ \\
\hline
\end{tabular}


1 AtgAAGACCTACAgTCGgGTCTCCGTCTTTGTCTTACTGGTTGCGATCTTGCACACGTCA

\begin{tabular}{lllllllllllllllllllll}
1 & $M$ & $K$ & $T$ & $Y$ & $S$ & $R$ & $V$ & $S$ & $V$ & $F$ & $V$ & $L$ & $L$ & $V$ & $A$ & $I$ & $L$ & $H$ & $T$ & $S$ \\
\hline
\end{tabular}

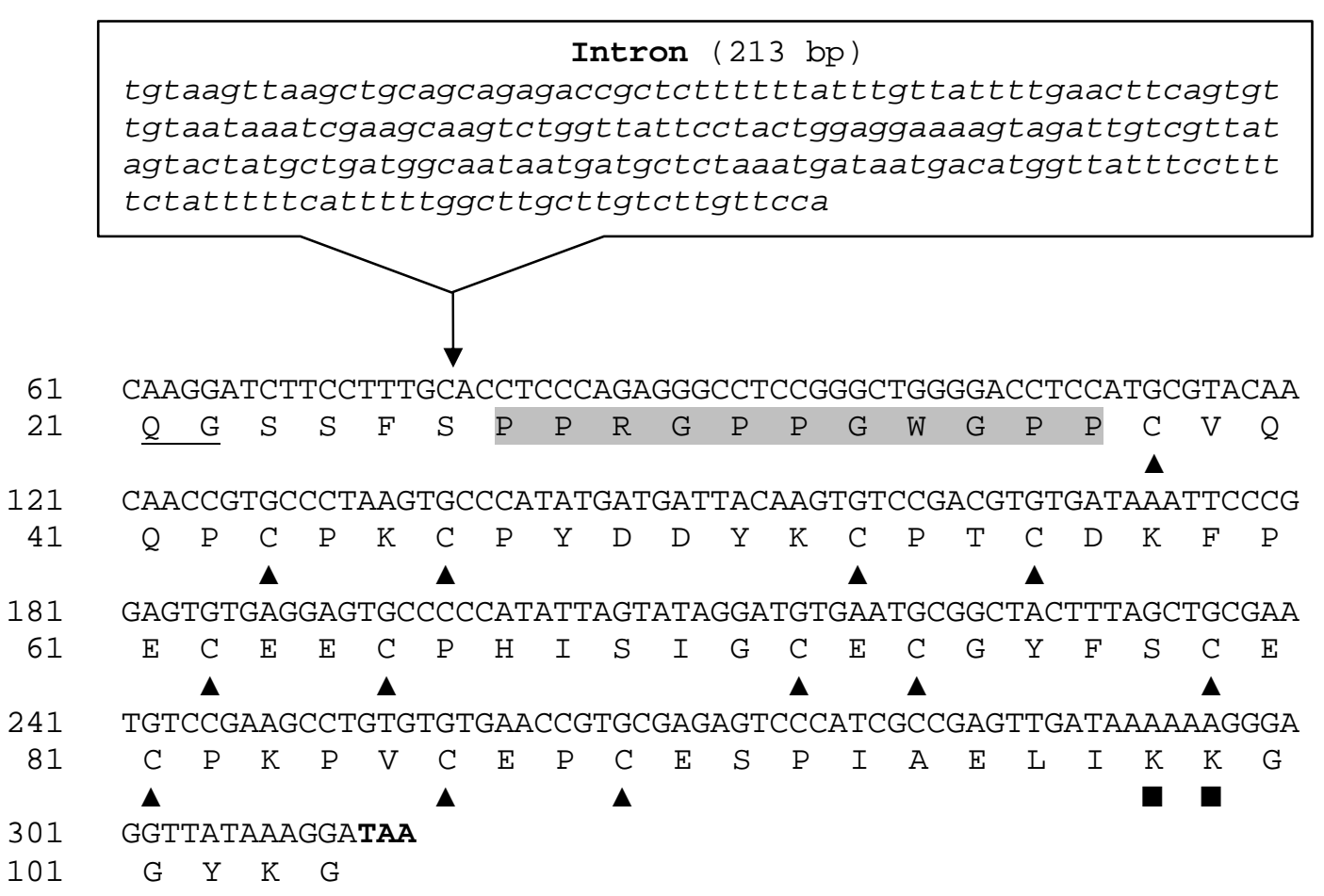

Fig.1. 
Ls-Stylicin1 MKTYSRVSVFVLLVAVLHTSQGSSFSPPRGPPGWGPPCVQQPCPKCPYDD

Ls - 2

$\mathrm{Pm}-1$

LV-1

LV-2 MKTYSRVSVFVLLVAIVHTSQGSSFAPPSRLPGWEPPCVPQQCPPCPYDD MRTFSQVSGFVLLVAIVRMSQGSSFYAPSGPPGERHPCPPQLCPVCPG - -

PQECPPCPYDD

MKTYSQVSVFVLLVAIAHTSQGSSFSPPRGPPGWKLPCVPQECPPCPYDD

Ls-Stylicin1

Ls - 2

$\mathrm{Pm}-1$

LV-1

LV-2

Fig.2.
51

YKCPTCDKFPECEE-CPHISIGCECGYF-SCECPKPVCEPCESPIAELIKKGGYKG

-ECPKCGGFPACEE-CPDIHIGCDCPFYHSCLCRQPVCEPCESPIAELIKKGGYKG - ECPKCESFPVCHEVCPDIAIGCDCPFYHSCECRHRVCPPCENPIAELIKKGGYNG - ECPKCEELPACEE-CPDIHIGCDCPFYHSCLCRQPVCEPCESPIAELIKKGGYKG

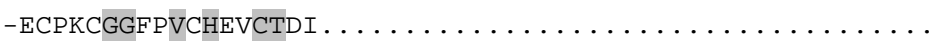




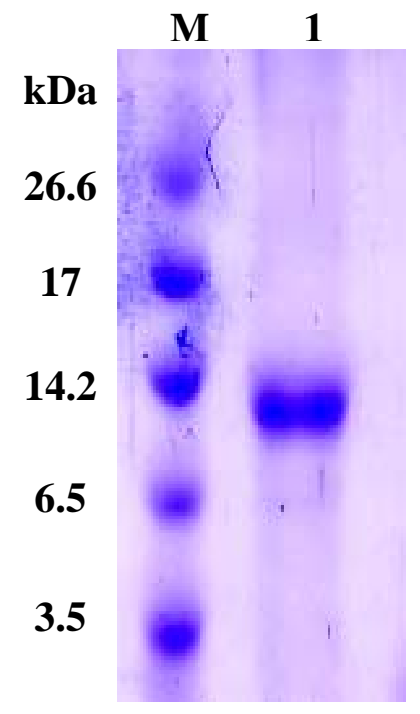

(A)

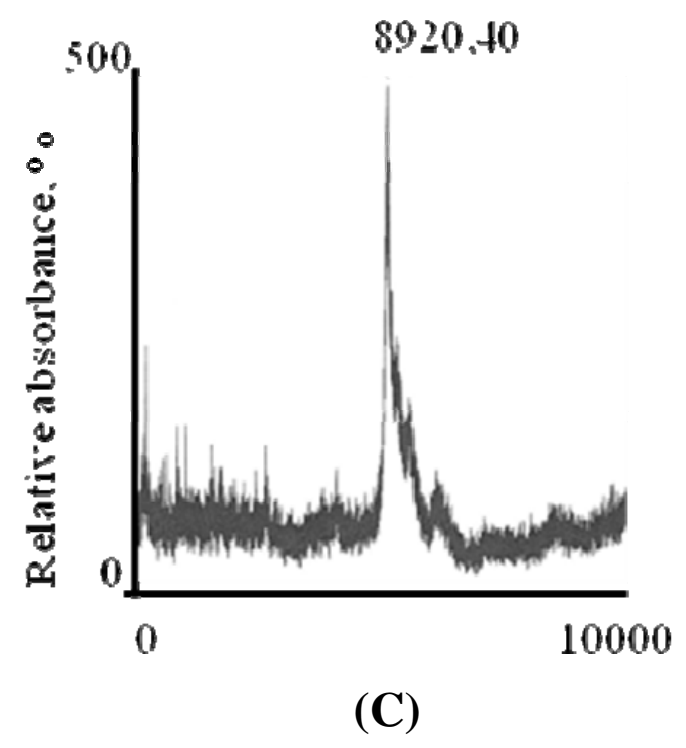

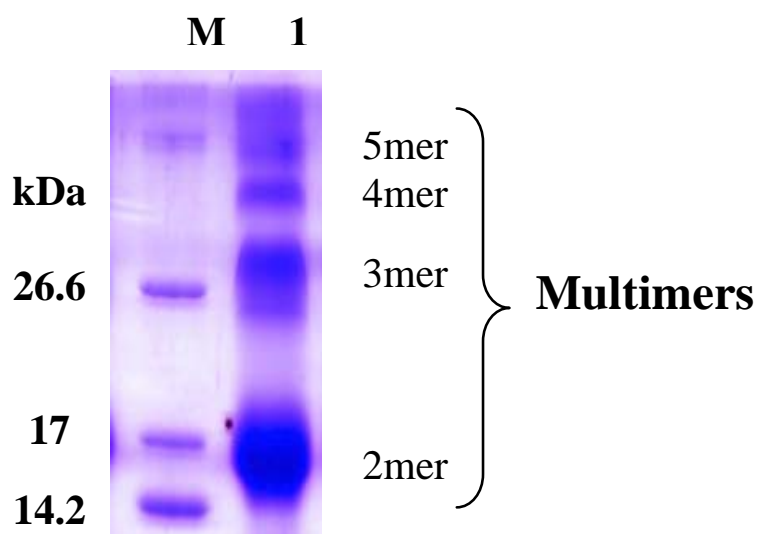

(B)

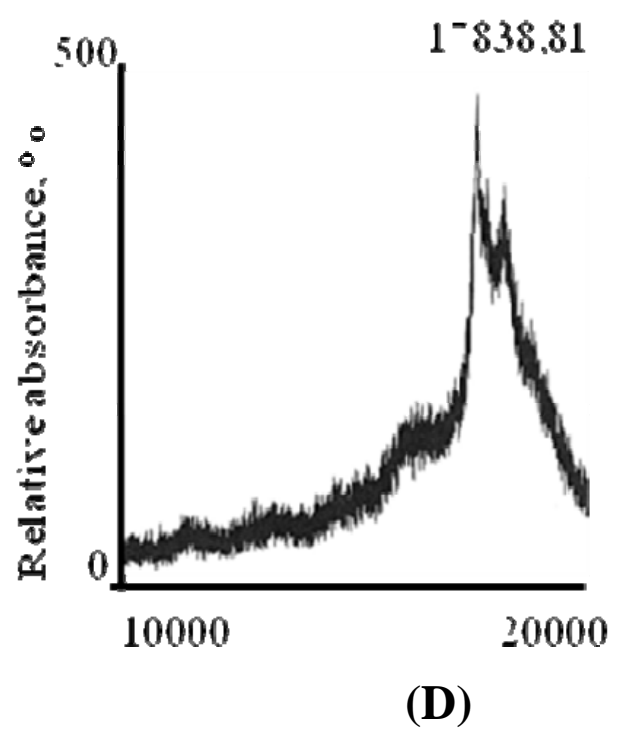

Fig.3. 


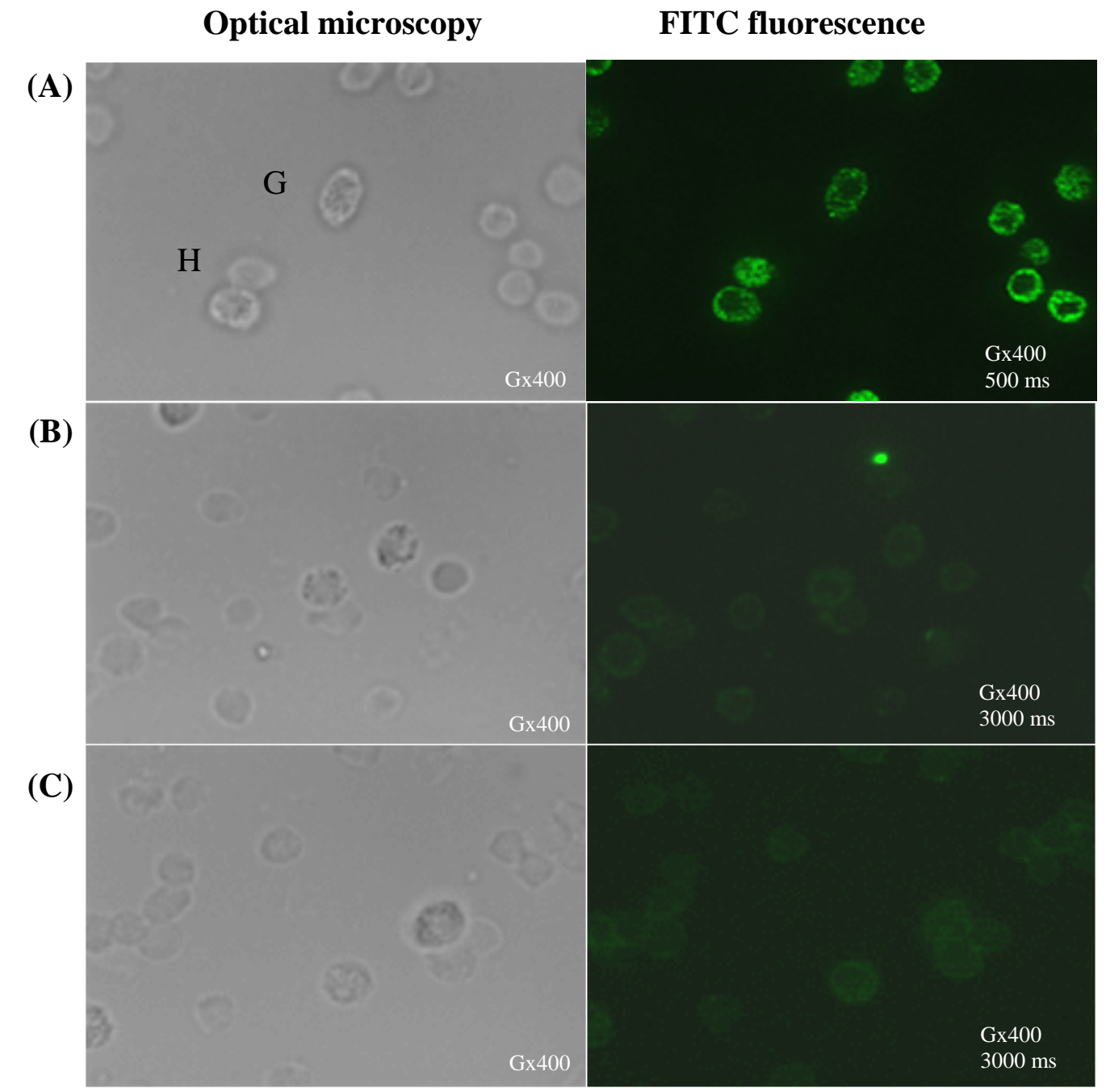

Fig.4. 

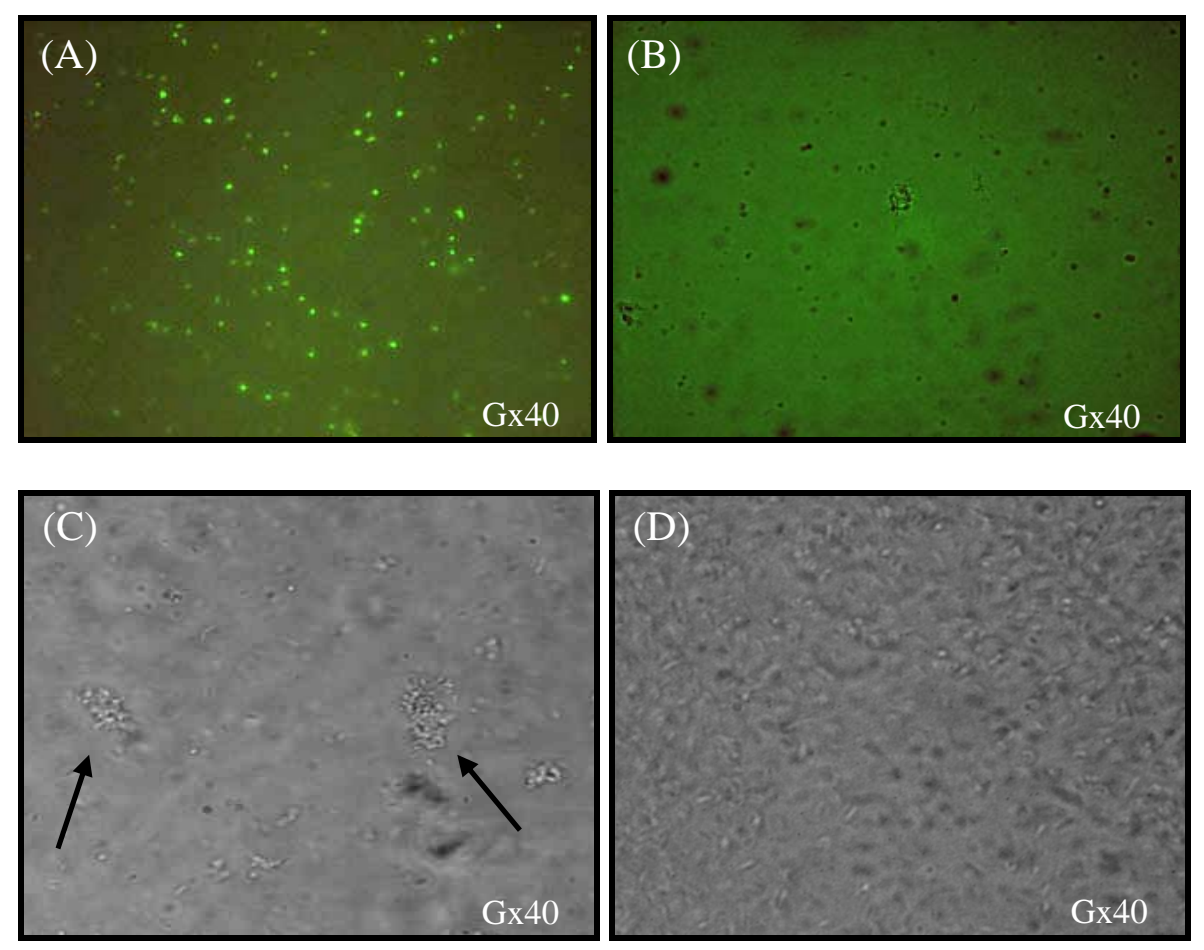

Fig.5. 


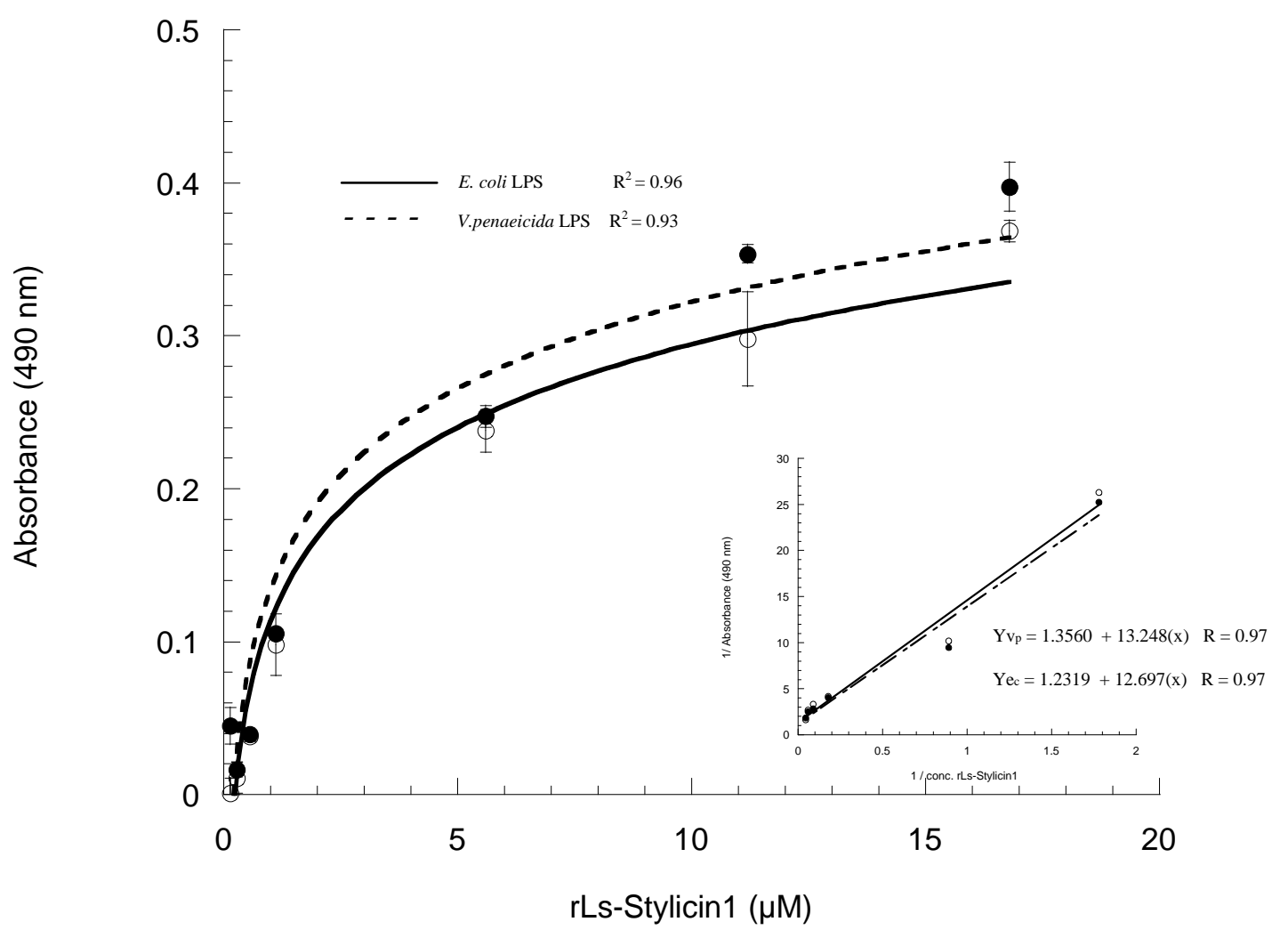

Fig. 6. 